\title{
Specific Pathogen Free Indicator
}

National Cancer Institute

\section{Source}

National Cancer Institute. Specific Pathogen Free Indicator. NCI Thesaurus. Code C158368.

An indication as to whether the subjects have been shown to be free of a specific pathogen. 